\title{
遺伝的アルゴリズムによる位相速度の逆解析 PHASE VELOCITY INVERSION USING GENETIC ALGORITHMS
}

\author{
山中浩明*, 石田 寞** \\ Hiroaki YAMANAKA and Hiroshi ISHIDA
}

\begin{abstract}
The applicability of genetic algorithms in an inversion of surface-wave phase velocities to infer an S-wave velocity profile was examined. S-wave velocities and thicknesses are coded to binary strings, and an individual model is generated by connecting all strings for a subsurface structure model. The fitness is defined by squared summation of differences between observed and calculated phase velocities. In addition to three basic genetic processes of selection, crossover, and mutation, the algorithm was improved by the introduction of elite selection rule and dynamic mutation in which the mutation probability varied according to the variety of individuals in a generation. We applied the method to the inversions of synthetic phase velocities and phase velocities from an actual array observation of long-period microtremors. These results indicate that the GA is highly applicable in phase velocity inversion.
\end{abstract}

Keywords : inversion, genetic algorithm, phase velocity, surface wave, microtremors, geophysical exploration

逆解析，遺伝的アルゴリズム，位相速度，表面波，微動，物理探査

\section{1.はじめに}

強震動特性を予測する際には，对象地点の地盤の影響 を考虑することが重要である。地盤の震動特性は経験的 または解析的に評価される。对象地点固有の地盤特性を より詳しく知るためには, 解析的手法が有用であると考 之られ，代表的な手法である S 波の 1 次元重複反射理論 による地盤の応答計算は耐震設計のためによく用いられ ている。解析的手法を適用する場合には, 地盤構造を知 る必要がある。そのために，いくつかの物理探査技術が 開発されている。その中で, 微動を用いる方法は経済的 な探査方法のひとつであると考えられる。微動に関する 研究は古くから行われており，最近の計測技術の発展に よっていろいろなタイプの観測が行われている”。とく に, 高い精度の観測が要求されるアレイ観測も比較的容 易に実施できるようになり，いろいろなサイズでのアレ イ観測が行われ 2),3),4)，地盤探查方法のひとつとして確立 されつつある。

微動のアレイ観測による地盤探查では, アレイ観測記
録から表面波成分が抽出され，いくつかの周期に対して 位相速度が求められる。次に，その位相速度と合うよう な理論分散曲線を有する地盤モデルが推定される。この ような解析手法は微動観測データだけでなく，地震動の アレイ観測記録による位相速度においても用いられてい る方法である5)。

こうした表面波の解析から地下構造を求める際には, 観測された位相速度の精度が高い場合には，最小 2 乗法 に基づいて逆解析が行われる。位相速度の理論值は平行

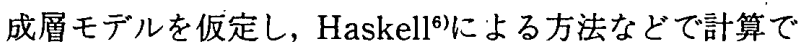
きるが,一般的には非線形なモデルとなる。そのために， 逆解析では観測方程式を疑似線形化し, 準ニュートン法 に代表される勾配法に従って繰り返し計算を行い，最適 解を求めている。最小にするべき目的関数としては位相 速度の理論值と観測值の誤差の 2 乗和が選ばれることが 多い。場合によっては制約条件やぺナルティー開数など が導入されることもある。位相速度が地下構造の変数に 対して非線形であるために，各変数に関する誤差の 2 乗
* 鹿島・小堀研究室 研究貝・工博

**鹿島・技術研究所 主任研究員・工修
Kobori Research Complex, Kajima Corp., Dr. Eng.

Kajima Technical Research Institute, Kajima Corp. 
和の曲面は複雑となり，多峰性であることが多い。その ために，勾配法による逆解析の結果は初期モデルに依存 することがある。これは勾配法では初期モデルによって は局所的な最小值に収束し, 大局的な最小值を探索でき ない性質を持っているためである。各種の土質または地 球科学的データがある場合には，適切な初期モデルが設 定され，大局的な最小值が勾配法でも得られることが期 待される。しかし，地殼の表層部分である堆積層におい ては構造が複雑で, 先駆的な情報が少なく, 適切な初期 モデルの設定が困難な場合が多い。さらに，初期モデル によっては繰り返し計算の途中で地盤の速度や層厚など の変数が負になる場合がある。こうした点を防ぐために いろいろな制約条件が設けられるが，勾配法では微分項 の計算が必要であり, 制約条件によってはその導入が困 難な場合もある。

このように, 位相速度の逆解析で用いられている勾配 法による非線形最小 2 乗法には実用上のいくつかの問題 点がある。ここでは, 位相速度の逆解析を例として問題 点を述へたが，それらは勾配法による多くの逆解析にお いて共通の問題であろう。この研究ではこれらの問題点 を解消するために, 勾配法とは全く別の考え方であり, 最近, 最適化問題の解法として注目されている遺伝的ア ルゴリズム（以下，GA）を表面波の位相速度の逆解析に 応用し，その適用性の検討を行った。とくに，微動のア レイ観測から S 波速度構造を推定する問題に GA を適 用することを主な目的とした。

\section{2. 遗伝的アルゴリズムについて}

GA は自然淘汰に基づく生物の進化過程を模擬した数 理的なモデルであり，1980年代後半からシステム設計な ど組み合わせ最適化問題の解法としての可能性が検討さ れている7゙。GAについては解説的な論文がいくつかあ $\eta^{8), 9), 10)}$ こここでは議論の展開のために GA の概要および 用いられている用語について説明する。

GAの基本的要素は変数の遺伝子コード化, 遺伝的操 作 (選択, 交差, 突然変異), 適応度の評価である。これ らは Fig. 1 のごとく関係している。探索対象となる変数 は実際の物理的な值 (表現型：phenotype)を表す問題空 間で定義されているが，GAにおいては問題空間の変数 は遺伝的操作に適した形（遺伝子型・genetype）にコー ド化される。したがって, 遺伝子コード化は取り扱う問 題に依存するが，連続変数の場合には 2 進数などのコー ドがよく用いられている。コード化された変数の個々の 要素を遺伝子と呼ぶ。2 進数の場合, 個々のビットが遺 伝子に对応している。遺伝子の集まりを染色体と呼び, 染色体の集まりを個体と呼ぶ。1変数の問題ではひとつ の個体は 1 つ染色体から作られるが, 多変数であれば, Uとつの個体は複数の染色体から構成されることにな る。こうした個体の集まりは集団と呼ばれる。Fig.1のよ
うに GA では遺伝子型の変数の笁間である GA 空間に おいて最適な変数の探索が行われる。遺伝子コード化で は，物理空間と GA 空間が 1 对 1 の对応になるようにす ることが望ましい。

各個体に対して Fig. 1 にあるように問題空間での変 数の物理的な值に基づいて適応度が定義される。これは 通常の最適化問題では目的関数に対応するものである。 GA では適応度の評価のみが問題空間で行われ，後述す る遺伝的操作は GA 空間で行われる。したがって，順問 題に対する計算が可能な問題であれば，微分計算が必要 ないので，簡単に GA を適用できる。これは GAのもつ 特長のひとつである。

GAの計算の手順がFig. 2 に示すごとくである。GA では最初に複数の個体の遺伝子を乱数によって発生させ て，初期集団を作る。初期集団のそれぞれの個体の染色 体に対して, 交差, 突然変異, 選択の 3 つの遺伝的操作 が行われる。そして，ある条件が成立するまで遺伝的操 作が繰り返される。このひとつのサイクルは世代と呼ば れる。

選択は現在の集団からそれぞれの個体の適応度に従っ てランダムに新しく同じ数だけ個体を選び, 次の世代の

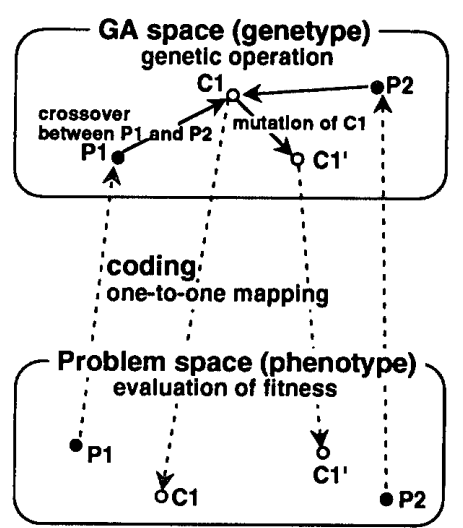

Fig. 1 Relation between GA space and problem space.

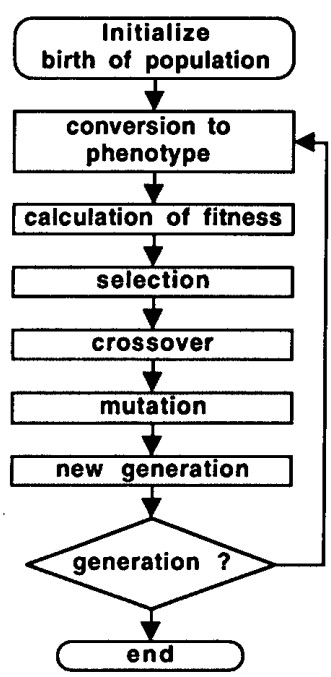

Fig. 2 Procedure of a genetic algorithm. 


\section{parent $1(10 / 1101)$ \\ parent 2 (Q1/10.01) \\ a) Crossover （交差）

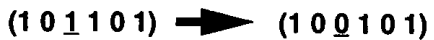 \\ b) Mutation （突然変異）}

Fig. 3. Example of crossover and mutation.

集団をつくる操作である。選択にはいくつかの方法があ ク，最も一般的に用いられているものはルーレット選択 に基づくものである。ある個体が $j$ が適応度 $f_{j}$ を有して いるとき，その個体が次世代の集団に選択される確率 $P_{j}$ は総個体数 $N$ の集団でのその個体の適応度により

$$
P_{j}=f_{j} / \sum_{k=1}^{N} f_{k}
$$

に基づいて決められ，ランダムに重複を許して次世代の $N$ 個の個体を選んでいく。

交差は現在の集団からランダムに 2 つ個体のペア （親）を作り，ランダムに選んだ遺伝子の位置で Fig. 3a のように2つ個体の染色体を入れ替え, 新しい2つの個 体（子）を作る操作である。Fig. 3a.の例では, 染色体の 1 ヶ所で入れ替えが行われており，1点交差と呼ばれる。 交差によってよい形質をもつ染色体の一部が交換され， より適応度の高い個体が現れることが期待される。最適 化問題としてみた場合には, 新しい探索点の発生に対応 している。

一方，突然変異では集団の中からある確率で個体をラ ンダムに選び，ランダムに選んだ遺伝子の位置で遺伝子 の值をFig. $3 \mathrm{~b}$ のように反転させる操作である。最適化 問題として考えれば，局所的な最小值に収束しそうに なった場合に, 突然変異によってそこからの脱出が可能 になると考えられる。ただし，突然変異の発生確率が高 すぎる，よい形質を持った染色体も破壊される可能性 があり，ランダム探索に近くなってしまう場合がある。

以上の遺伝子レベルの操作を繰り返すことによって, ランダムに発生させた初期世代の集団を適応度が最も高 い個体，つまり最適解近傍へと収束させていく。

\section{3. 位相速度の逆解析への適用}

はじめに述べたように, 勾配法による位相速度の逆解 析には局所収束や計算の不安定さなどの実用上のいくつ かの問題点がある。一方, 最適化問題としての GA では 交差と突然変異によって広域探索と局所探索が可能と なっている。さらに, GA では微分や逆行列の計算が不要 であり，目的関数や制約条件の制限が少なく， ロバスト 性が高く，しかも初期モデルが不要であるなどの利点が ある。また, 遺伝すると言う意味で, 過去のサンプルの 評価も利用しており，ランダム探索とも異なっている。 こうした最適化手法としての GA の長所によって, 勾配 法による位相速度の逆解析における実用上の問題点を解 決できると考えられる。
ここでは，微動アレイ観測の解析で使われることが多 いレイリ一波の位相速度の逆解析を例にして，GAの適 用方法について述べる。しかし，基本的には群速度やラ ブ波についても同様である。

水平成層ではレイリー波の位相速度は周期の関数とな $\eta$, その関数形は地盤の $\mathrm{P}$ 波速度, $\mathrm{S}$ 波速度, 層厚, 密 度によって決まる。通常の最小 2 乗法による逆解析と同 様に GAによる逆解析でもすべての変数を未知数とす ることが可能である。しかし,これらの中で, 層厚と $\mathrm{S}$ 波 速度の変化が位相速度に对しての影響が大きいことが知 られている2゙。そこで, 位相速度の逆解析において P 波速 度や密度は固定されるか2), $\mathrm{S}$ 波速度との関係式によって $\mathrm{S}$ 波速度と連動するように扱われている3。以下では， $\mathrm{S}$ 波速度と層厚を未知数として，GAに基づいた位相速度 の逆解析方法について述べる。

変数の遺伝子コード化では各層の S 波速度と厚さに ついて探索範囲の上限と下限を決め，その間を $2^{n}$ に離散 化し, $n$ ビットから成る 2 進数に変換する ${ }^{11)}$ 。つまり, 各 層の S 波速度と層厚はそれぞれ $(0,0, \ldots, 0)$ から $(1,1$, $\ldots, 1)$ の間に分布する染色体にコード化されることにな る。 $M$ 層からなる地盤モデルでは, 各層の $\mathrm{S}$ 波速度と層 厚に対する染色体が順に連結され，ひとつの個体となる。 最下層が半無限媒質であるとすれば，ひとつの個体は $n$ $\times(2 M-1)$ ビットの染色体長を持つ染色体となる。

適応度については従来の勾配法による最小 2 乘法のよ うに微分項の計算の必要がないので，かなり自由に設定 できる。前述したように適応度は選択の基準になるので, 基本的には観測された位相速度と地盤モデルに対する理 論位相速度との一致の程度が高いほど，適応度が高くな るように設定すればよい。，また，ルーレット選択などを 用いる場合には，適応度を常に正值にする必要もある。 ここでは, 最小 2 乗法と同様に, 周期 $T_{i}$ に对して観測さ れた位相速度 $c_{0}\left(T_{i}\right)$ と理論値 $c_{c}\left(T_{i}\right)$ の鿁差の 2 乗平均 値の逆数として個体 $j$ について適応度 $f_{j}$ を

$$
f_{j}=\frac{1}{\frac{1}{L} \sum_{i=1}^{L}\left[C_{0}\left(T_{i}\right)-C_{c}\left(T_{i}\right)\right]^{2}}
$$

と定義する。ここで，Lは周期ごとに観測された位相速 度の数である。また，この適応度の逆数である誤差の 2 乗平均值を misfit と呼ぶ。適応度の計算に必要な位相速 度の理論值は Haskell'bによる方法で計算する。また，P 波速度は狐崎ら ${ }^{12)} に よ る \mathrm{~S}$ 波速度との関係式

$$
V_{p}=1.11 V_{s}+1290(\mathrm{~m} / \mathrm{s})
$$

によって $\mathrm{S}$ 波速度と連動させ, 密度については各層で一 定値とする。

観测された位相速度について何らかの形で分散が明ら かになっている場合には, 分散 $\sigma\left(T_{i}\right)$ で位相速度の誤差 を正規化し, 


$$
f_{j}=\frac{1}{\frac{1}{L} \sum_{i=1}^{L}\left\{\frac{C_{0}\left(T_{i}\right)-C_{c}\left(T_{i}\right)}{\sigma\left(T_{i}\right)}\right\}^{2}}
$$

によって適応度を評価する。

選択ではルーレット規則に従って，それぞれの個体の 選択確率を式(1)に基づいて決め，適応度の総和を 1 に正 規化し， 0 から 1 の乱数を $N$ 個だけ発生させて, 現在の 世代の集団から重複を許して次の世代の $N$ 個の個体を 選んでいく。

選択で新しく発生したすべての個体はランダムに $2 つ$ の個体のぺアに分けられ，交差が行われる。各ペアごと に0から1の乱数をひとつ与え，それが与えられた交差 確率 $P_{c}$ を下回った場合に，交差を行うことにする。ひと つの個体は複数の変数に对する染色体から構成されてい るので, 交差は各変数に対応する染色体ごとに乱数で選 んだ 1 点で 1 点交差を行うことにする。したがって，個 体レベルでみれば, 多点交差となっている。

交差の後に, 突然変異の操作が行われる。突然変異確 率 $P_{m}$ を与之，すべての個体のすべての遺伝子に对して 0 から 1 に分布する乱数をひとつ与之, その乱数が $P_{m}$ を下回った場合にその遺伝子位置のビットを 1 から 0 ま たは 0 から 1 に反転させる。

以上の操作を指定世代数だけ繰り返して, 計算を終了 する。収束の状況は各世代の個体の中での最小 misfit 值 の推移で評価し, 全世代を通じて最小の misfit 值をもつ 個体を 1 回の試行での最適解とする。さらに, GA は最適 解の確率的探索方法であるので，安定した解を得るため に乱数の初期值を変えて複数回の試行を行うことにす る。

以上のような操作から構成される GA は単純 GA と 呼ばれている。さらに最適解の探索能力を向上させるた めに単純 GAにいくつかの操作を加える。ここでは, 動 的突然変異とエリート選択の導入についての検討を行 う。同じ染色体を有する個体が集団の多数を占めると, 局所収束になりやすくなる。そこで，集団の収束状況に 応じて突然変異確率を変化させることを考之る。各世代 の集団が収束せず，集団に多様性がある場合には，交差 が効果的に働くように突然変異確率を低く抑之，集団が 均質に近づいてきた時には，突然変異確率を大きくし， 集団の多様性を確保する。その結果，大局的な探索が常 に可能になると考えられる。個体の多様性の指標として, 1 つの集団での $N$ 個の個体の各変数 $x_{i j}$ の分散

$$
\sigma_{i}=\left\{\frac{\sum_{j=1}^{N}\left(x_{i j}-\bar{x}_{i}\right)^{2}}{N}\right\}^{1 / 2} .
$$

を求め, それを各変数の集団での平均值 $\bar{x}_{i}$ で正規化し, すへてての $\mathrm{M}$ 個の変数について平均した值

$$
\gamma=\frac{1}{M} \sum_{i=1}^{M}\left(\frac{\sigma_{i}}{\bar{x}_{i}}\right)
$$

を各世代での選択の操作の後に計算し， $\gamma$ の值によって 突然変異確率を変化させて, 突然変異を行う。以下，こ の操作を動的突然変異を呼ぶ。

後述のとおり, 突然変異確率が高過ぎると, 適応度の 高い個体の染色体まで破壊する場合がある。これを防ぐ ために, ルーレット選択に加え，エリート選択を行う。 これは新しく生じた世代の集団の最小 misfit 值が前世 代での最小 misfit 值より大きい場合には, 強制的に前世 代の最小 misfit 值の個体を新しい世代の集団の中に入 れ，その代わりに新しい世代の中で misfit 值が最も大き い個体（誤差が大きい地盤モデル）を取り除く操作であ る。一般に，エリート選択のみでは局所収束に陥りやす いとの指摘があるが13)，動的突然変異と合わせることで 収束を速くすることに関して効果的に働くと期待され る。

\section{4. 数值実験結果}

\section{$4.1 \mathrm{~S}$ 波速度のみを変数とした場合}

まず, 単純な例として各層の層厚が既知であり，S 波速 度のみが未知数である場合について単純 GAによる逆 解析の数値実験を行った。

用いた地盤モデルは Table 1 に示すごとく 4 層から 構成されている。この研究では周期 1 秒以上のやや長周 期微動のアレイ観測によるレイリ一波の位相速度の逆解 析へ GA を応用することを主な目的のひとつとしてお ク,この地盤モデルは地震基盤までの樑い地盤を想定し たものである。この地盤モデルに対する基本モードのレ イリー波の理論位相速度が Fig. 4 に示されている。この 数值実験では Fig. 4 の位相速度のうち周期1.5-8 秒の 間でほほ等間隔にサンプリングされた19個の周期に对す る理論値を観測值と仮定した。各層の $\mathrm{S}$ 波速度の探索範 囲も Table 1 に示されており, 層厚と密度は理論值を計 算した值に固定した。それぞれの層に対する $\mathrm{S}$ 波速度は 6 ビットで離散化され，2 進数の遗伝子型データにコー

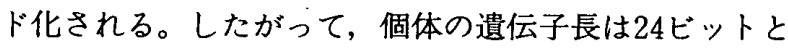
なる。

前述のように, GA では交差確率 $\left(P_{c}\right)$, 突然変異確率 $\left(P_{m}\right)$, 綕個体数 $(Q)$ など設定するべき变数がある。こ れらを決定する厳密な基準は現在のところ明らかではな 〈9), GA を適用する問題ごとにチューニングする必要が

Table 1 Test model

\begin{tabular}{|c|c|c|c|c|}
\hline & & True model & Search area \\
\cline { 2 - 5 } & $\mathrm{Vs}(\mathrm{km} / \mathrm{s})$ & $\mathrm{H}(\mathrm{km})$ & $\rho\left(\mathrm{g} / \mathrm{cm}^{3}\right)$ & $\mathrm{Vs}(\mathrm{km} / \mathrm{s})$ \\
\hline 1 & 0.6 & 0.4 & 1.8 & $0.2-1.0$ \\
\hline 2 & 1.0 & 0.5 & 2.0 & $0.5-1.5$ \\
\hline 3 & 1.5 & 0.6 & 2.3 & $0.8-2.0$ \\
\hline 4 & 3.2 & $\infty$ & 2.5 & $2.8-3.8$ \\
\hline
\end{tabular}
between Vp and Vs by Kitsunezaki et al. (1990). 


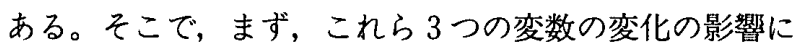
ついて検討する。

$P_{c}, P_{m}, Q$ のjち 1 つを変化させ, 残り 2 つを固定し て, 計算を行い, 各世代の最小 misfit 値の収束状況を比 較した。Fig. 5(a)は $P_{c} ， Q$ をそれぞれ70\%，20として， $P_{m}$ を $0 \%$ か $10 \%$ まで 4 段階に変化させたときの各世 代の最小 misfit 值を示している。5 世代まではどの場合 も同様の傾向である。しかし，5世代目以降では $P_{m} に よ$ る差異が認められる。 $P_{m}$ が $0.1 \%$ 以下と小さい場合には， 5 世代目でほぼ一定值に収束してしまい，それ以降の世 代では，より misfit 值の小さい個体は生じていない。一 方， $P_{m}$ が1\%または10\%の場合には，20世代目までは次

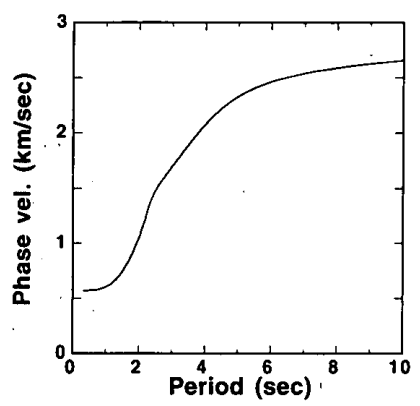

Fig. 4 Phase and group velocity dispersion curves of fundamental Rayleigh wave in the subsurface structural model shown in Table 1. The phase velocities in a period range from 1.5 to $8 \mathrm{sec}$ are used for the test of $\mathrm{GA}$ inversion.
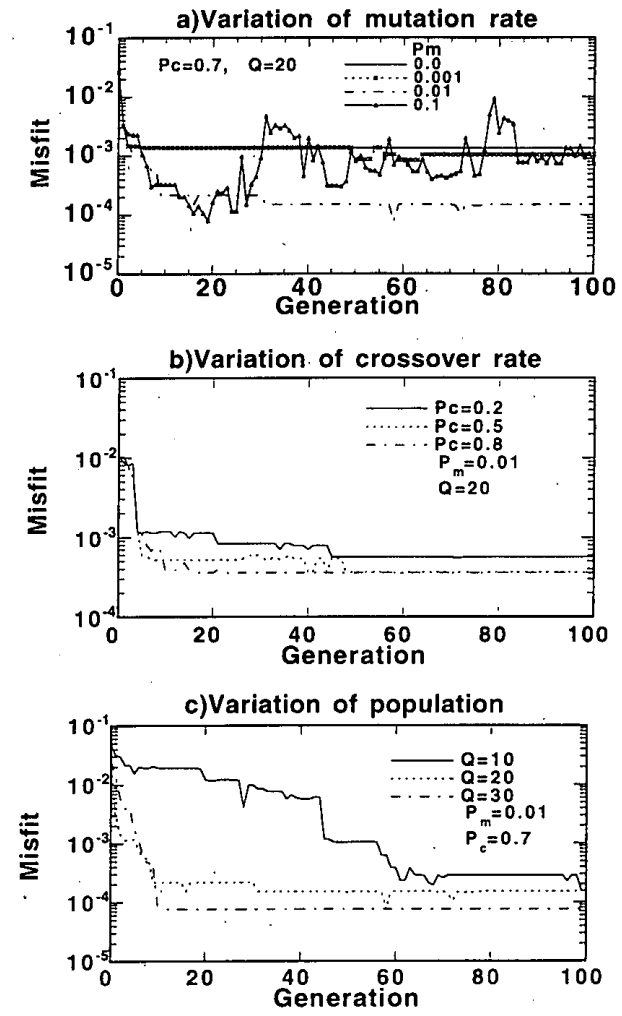

Fig. 5 Comparison of convergence of misfit values due to increasing generation between the inversions of synthetic phase velocities in Fig. 4 with different (a) mutation probabilities, (b) crossover probabilities, and (c) population sizes.
第に misfit 值は小さくなり， $P_{m}$ が小さい場合に比べ，よ り観測値に合うモデルが得られている。しかし， $P_{m}$ が 10\%と大きい場合には，20世代以降で収束せず，約30世 代目で misfit 值は $P_{m}$ が $0 \%$ の場合より大きくなってい る。これは乫然変異によって misfit 值がより小さい個体 の染色体が破壊されるためである。このように突然変異 によって局所的な収束を防ぎ，より広域な探索が可能と なるが, 一方で適応度の高い遺伝子列も壊してしまう場 合があるので, 注意が必要である。

つぎに, 交差確率 $P_{c}$ にいて検討する。 $P_{m}, Q$ を $1 \%$, 20 として, $P_{c}$ を $20 \%, 50 \%, 80 \%$ と変化させた結果が Fig. 5 (b)に示されている。P $P_{c}$ が低い場合には，遺伝子の情報の 交換が少なくなり，収束が遅くなっている。しかし， $P_{c} 50 \%$ 以上ではほぼ同様の収束状況となり，ある程度高 い交差確率があれば，収束状況にはあまり変化がないと 考えられる。

Fig. 5 (c)は $P_{c} 70 \% ， P_{m} 1 \%$ ととして，綕個体数 $Q$ を $10 ， 20 ， 30$ と変化させたときの収束状況を示している。 $Q$ が大きいほど， misfit值が小さい個体が得られてい る。GA では複数の個体を用いて並列に探索を行ってい るので, 総個体数が多くなるほと, 探索能力は向上する。 しかし，個体数が多くなると，計算時間が長くなるので, 収束が顕著に遅くならない程度に個体数を少なくするこ とか望ましい。この場合には $Q$ は20が適当であると考え ら扎る。

上記の検討から，総個体数を20，交差および突然変異 確率をそれぞれ70\%，1％に設定し，100世代までの計算 を行うことにする。さらに，乱数の初期值を変えて20回 の試行を行う。

計算結果の 1 例として, Fig. 6 には 4 つの層の S 波速 度が世代の更新に従って変化していく状況が示されてい る。それぞれの网はひとつの世代に存在するすべての個 体の状況を示している。円の中心までの距離が $\mathrm{S}$ 波速度 の值であり, 同一半径上に並ぶ 4 つの点がひとつの個体 に对する各層のS 波速度に対応している。ランダムに発 生させられた初期世代では各層の S 波速度は個体毎に ばらついている。しかし，世代の更新に従って，多くの 個体の各層に対する S 波速度は同心円上に並んでおり， ほぼ一定の值に収束している。しかし，ほほ収束してい ると考えられる10世代目以降でも，突然変異によって収 束している值からはずれた S 波速度を持つ個体も現れ て，新しい探索点の模索が行われていることがわかる。

Fig. 7 には各世代で得られた最小 misfit 值の変化が20 回の試行の平均值として示されている。30世代程度でほ ぼ収束している。20回の試行の結果から試行ごとに最小 misfit 值を示す解が得られる。これら20個の地盤モデル について各層ごとに $\mathrm{S}$ 波速度を平均して得られる平均 地盤モデルが標準偏差とともに Fig. 8 に示されている。 
逆解析によって推定されたモデルはほぼ正解值となって いることがわかる。

\section{2 動的突然変異およU゙エリート選択の導入}

Fig. 7 のように集団は約30世代で収束し，それ以降で は，大幅に misfit 值は小さくなっていない。これは世代 更新が進んでくると，選択と交差の結果，染色体が類似 している個体の数が集団の大半を占めて，交差により新 たな探索点が模索されにくいことが原因であると考えら れる。しかし, Fig. 5 (a)で示されているように, 突然変異
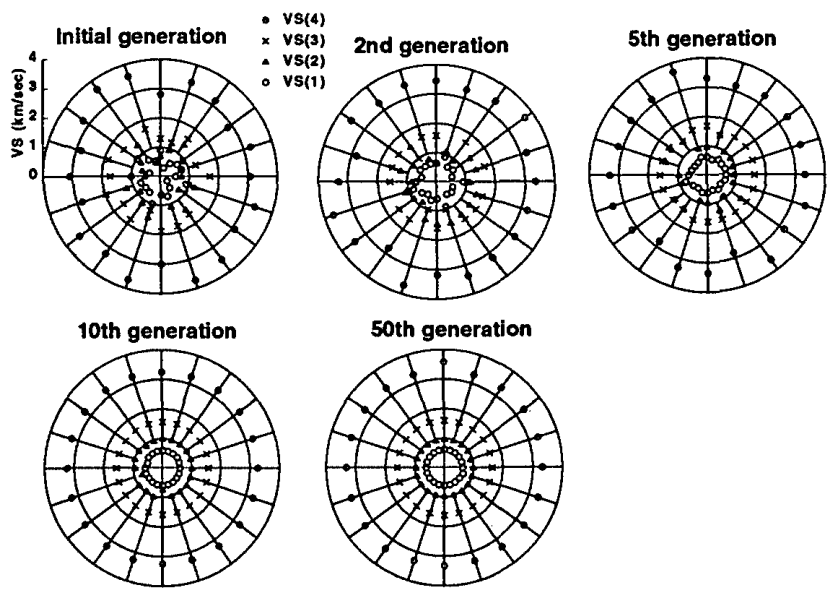

Fig. 6 Variation of shear wave velocities in all models in several generations for the inversion of the synthetic phase velocities. All individuals in a generation are indicated in a large circle, An individual model has four S-wave velocities arranged in the same azimuth. The distance from the center corresponds to $\mathrm{S}$-wave velocity.

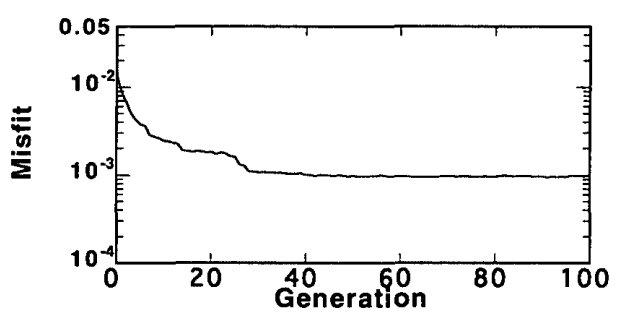

Fig. 7 Plot of misfit values against generation for the simple GA inversion of the synthetic phase velocities in Fig. 4. Only S-wave velocities are parameterized. Results of 20 calculations with different random values are averaged.

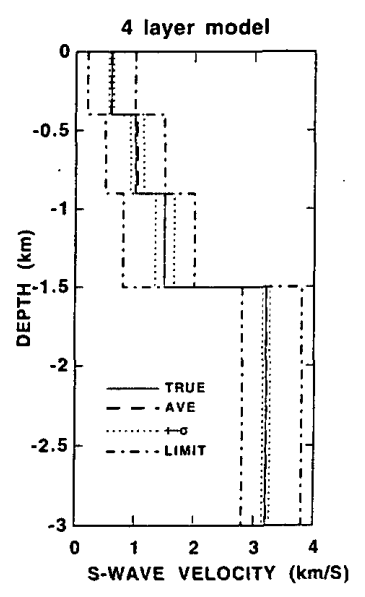

Fig. 8 Comparison between the true model (thin line) and model obtained from averag ing 20 models obtained by the GA inversions with different random values (broben line). Stan dard deviation for the inverted models is also shown by dotted lines, and search area is indicated by dashdotted lines. Only Swave velocities were parameterized in the inversion.
が局所収束からの脱出に効果的であることから，動的突 然変異を導入することにする。式(6)に基づいて $\gamma$ の值を 世代更新ごとに計算し，それによって突然変異確率 $P_{m}$ を

$$
\begin{array}{ll}
P_{m}=1.0 \% & 0.1 \leqq \gamma \cdots \cdots . . . \\
P_{m}=5.0 \% & 0.02 \leqq \gamma \leqq 0.1 \\
P_{m}=10.0 \% & 0.02 \geqq \gamma
\end{array}
$$

のように変化させて，突然変異を行った。さらに，適応 度の高い個体の染色体が破鲕されることを防ぐために， エリート選択も加える。

以上の操作を単純 GA に加えて，前述の場合と同様の 条件で20回の計算を行った。Fig. 9 は世代ごとの最小 misfit 值の推移を示している。約10世代目までは, Fig.7 に示されている突然変異確率を $1 \%$ に固定した場合と同 様の傾向であるが，それ以降でより misfit 值の小さい個 体が見つけられており，この改良によって最適解の探索 能力が向上していることがわかる。20回の試行から得ら れた最小 misfit 值を示す個体の $\mathrm{S}$ 波速度を平均した地 盤モデルがFig. 10 に示されている。突然変異確率を $1 \%$ 固定した計算結果である Fig. 8 の地盤モデルと 比べると, 試行ごとの S 波速度についての分散が少なく なっており，より信頼性の高い逆解析結果が得られてい

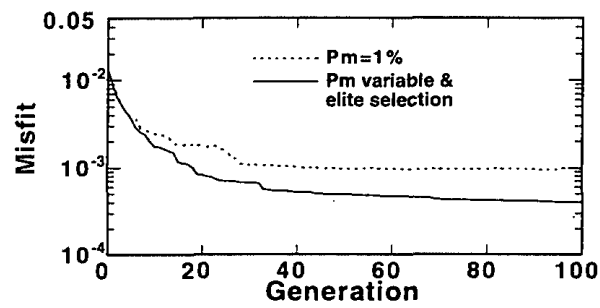

Fig. 9 Plot of misfit values against generation for the GA inversions of syhthetic phase velocities in Fig. 4, In the inversion, only S-wava velocities are parameterized, Solid and dotted lines indicate the plots for simple GA inversion and GA inversion with elite selection and dynamic mutation, respectively. Results of 20 calculations with different random values are averaged.

Fig. 10 Comparison between true model (thin line) and model obtained from averaging 20

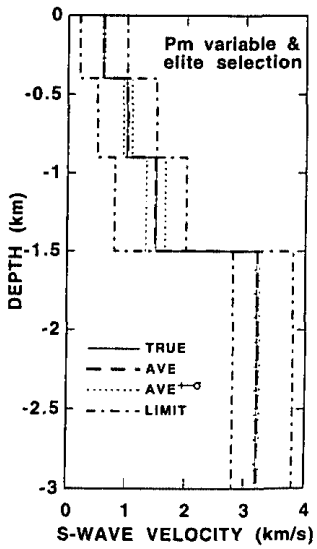
models obtained by the GA inversions with different ran dom values (broken line). Standard devia tion for inverted models is also shown by dotted lines, and search area in in dicated by dash. dotted lines. In the inversion only $\mathrm{S}$. wave velocities were parameterized, and elite selection and dynamic mutation were introduced. 
る。

\section{$4.3 \mathrm{~S}$ 波速度と層厚を変数とした場合}

$\mathrm{S}$ 波速度だけでなく，層厚も変数としてて GAによる位 相速度の逆解析を行った。地盤モデルは上記の例と同じ 4 層モデルである。用いた位相速度の周期帯域も同様で ある。各 S 波速度と層厚の探索範囲は Table 2 のごとく であり,すべての変数を 6.ビットで離散化した。したがっ て, 染色体長は 42 ビットとなる。総個体数は 20 , 交差確 率は $70 \%$, 動的突然変異, エリート選択の扱いも S 波速 度のみを変数とした場合と同様である。100世代までの計 算を乱数を変えて20回行った。

Fig. 11 は最小 misfit 值の世代に対する推移を示し, ほぼ40世代で収束している。Fig. 12 には20回の試行の結 果で得られた平均地盤モデルが示されている。第 3 層目 に対する S 波速度と層厚の分散が多少大きいが，逆解析

Table $2 \cdot$ Search aren

\begin{tabular}{|c|c|c|}
\hline & Vs. $(\mathrm{km} / \mathrm{s})$ & $\mathrm{H}(\mathrm{km})$ \\
\hline 1 & $0.4-0.8$ & $0.2-0.6$ \\
\hline 2 & $0.5-1.5$ & $0.3-0.7$ \\
\hline .3 & $0.8-2.0$ & $0.4-0.8$ \\
\hline 4 & $2.8-3.8$ & $\infty$ \\
\hline
\end{tabular}

※ $\mathrm{P}$ wave velocity is assumed from the relation between $V p$ and $\mathrm{Vs}$ by Kitsunezaki et al. (1990).

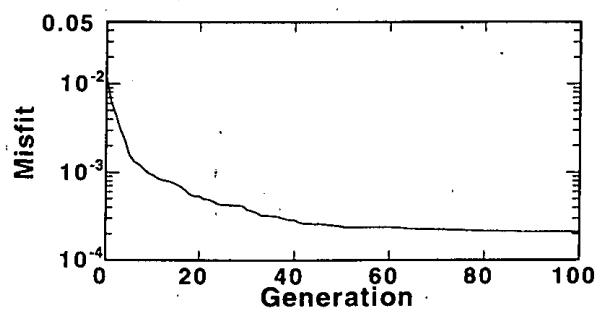

Fig. 11 Plots of misfit values against generation. In the inversion, S-wave velocities and thicknesses are parameterized, and elite selection and dynamic mutation were also introduced. Results of 20 calculations with different random values are averaged.

Fig. 12 Comparison between true model (thin line) and model obtained

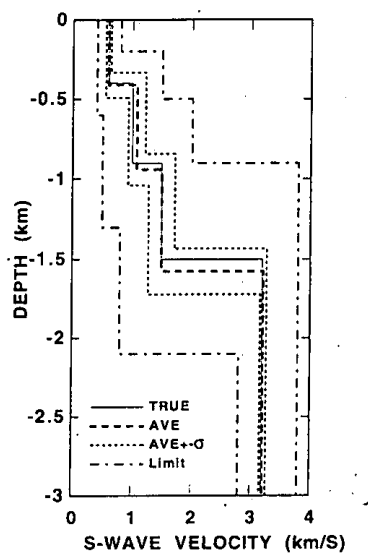

from averaging 20 models obtained by the GA inversions with different random values (broken line). Standard deviation for inverted models is also shown by dotted lines, and search area is in. dicated by dashdotted lines. In the inversion S-wave velocities and thick. ness are parameterized, and elite selection and dynamic mutation were also introduced.
で得られた地盤モデルの平均值はほぼ正解値に等しく なっている。Fig. 10 の 波速度のみを変数とした場合の 逆解析結果に比へ，深い部分の S 波速度の試行毎のばら つきは多少大きくなっ.ているが，平均值はほとんど同様 で, 正解值付近になっており, S 波速度と層厚を変数とし ても，GAによる逆解析によって大局的な最小值を探索 できると考えられる。

\section{5. 微動アレイ観測による位相速度の逆解析}

\section{1 首都圏西部での微動アレイ観測の概要}

4 章で述べた GA による位相速度の逆解析方法を実 際に微動アレイ観測によって得られた位相速度に対して 適用する。アレイ観測は東京都調布市周辺で地震基盤ま での深い地盤のS 波速度構造を調查することを目的と

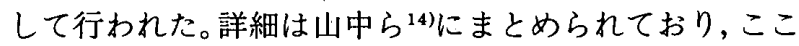
ではその概要を述べる。

観測では，直径約 $2 \mathrm{~km}$ の円内の10地点に設置された 小型長周期地震計によって周期 1 秒以上の微動の上下成 分が記録された。そして, $f-k$ スペクトル解析によって周 期.1 秒から 5 秒の間でレイリ一波の位相速度が得られて いる。さらに，その位相速度から準ニュートン法のひと つである Marquardt 法 ${ }^{15)}$ によって逆解析が行われ, S 波 速度構造が推定されている。その際には，層厚のみが変 数とされ, $\mathrm{P}$ 波および $\mathrm{S}$ 波速度はアレイ観測地域の数キ 口西にある梁層ボーリング孔で実施された VSP（Vertical Seismic Profiling) 探査 ${ }^{16)}$ にる值に固定されてい る。そして, 初期モデルとしてはVSP 探査から得られた 層厚が使われている。つまり，初期モデルとしては，極 めて良いものであった。

\subsection{GA による逆解析}

微動アレイ観測記録の $f-k$ スペクトル解析から各周期 ごとに得られた位相速度は Fig: 13 に示されている。各 周期の位相速度に対して分散も得られているので，適応

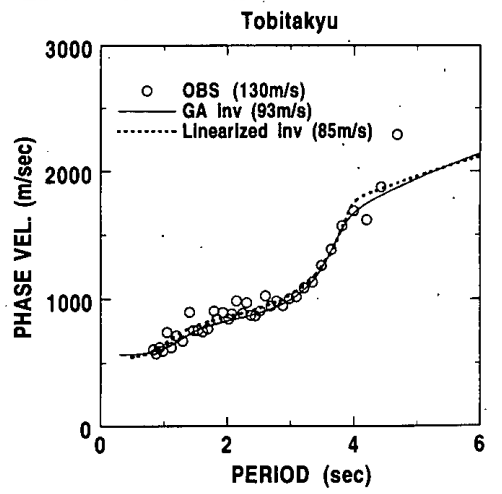

Fig. 13 Comparison of observed phase velocities with those for inverted models. Solid circles indicate Rayleigh wave phase velocities obtained from the array measurements of long-period microtremors in the western part of Kanto Plain ${ }^{14}$. The fundamental Rayleigh wave phase velocities calculated for the models estimated from.GA inversion and a linearized inversion ${ }^{14)}$ depicted in Fig. 16. are shown by solid and dotted lines, respectively. 
度の計算には(4)式を用いた。山中ら ${ }^{14)} の$ 逆解析ではVSP 挆査の情報から 7 層モデルを仮定している。ここでは， 先駆的情報がない場合を考える。一般に，関東平野の地 質構造は第四紀層，2つの第三紀層（上総層群，三浦層 群)と先第三紀の基盤から構成されていると考えられる。 そこで，4層モデルを仮定し, S 波速度および首厚を変数 とした GAによる逆解析を行う。各層に对する S 波速度 と層厚の探索範囲が Table 3 に示されている。S 波速度 と層厚にはトレードオフの関係があることもあり，この 逆解析では S 波速度の探索範囲をやや狭くし，層厚の探 索範囲を広くした。それぞれの変数は 6 ビットの 2 進数 でコード化されており, 染色体長は48となる。P波速度は (3)式によって S 波速度と連動させ, 密度は Table 3 の値 に固定している。個体数を40, 交差確率を70\%とし, 動 的突然変異確率は(7)式に従った。計算は50世代まで繰り 返し，乱数の初期值を変えて10回の試行を行った。

Fig. 14 は各世代の最小 misfit 值の推移を10回の平均 值で示している。ほぼ10世代で収束し，それ以降では10 回の試行ごとに得られる最小 misfit 值のばらつきは小 さくなっており，大局的な最小値に達していると考えら れる。Fig. 15 には得られた地盤構造モデルが探索範囲と ともに示されている。基盤のひとつ上に存在する層の層 厚に対する分散が多少大きくなっている以外は，ばらつ きが少なく精度よく推定されていると考えられる。

前述のごとく, 同し位相速度を用いて準ニュートン法 による逆解析がすでに行われ， $\mathrm{S}$ 波速度構造が得られて いる14)。こで, GAによる逆解析からの地盤モデル, 準 ニュートン法による逆解析からの地盤モデル14)および VSP 探查による地盤モデル15)を比較した(Fig. 16)。GA による逆解析モデルでは 4 層モデルであり, 深さ 1 ～1.5

Table 3 search area

\begin{tabular}{|c|c|c|c|}
\hline & $\mathrm{Vs}(\mathrm{km} / \mathrm{s})$ & $\mathrm{H}(\mathrm{km})$ & $\rho\left(\mathrm{g} / \mathrm{cm}^{3}\right)$ \\
\hline 1 & $0.2-0.7$ & $0.05-0.85$ & 1.8 \\
\hline 2 & $0.5-1.2$ & $0.05-1.25$ & 2.0 \\
\hline 3 & $1.1-1.8$ & $0.05-1.25$ & 2.2 \\
\hline 4 & $2.5-3.5$ & $\infty$ & 2.5 \\
\hline
\end{tabular}

relation between $\mathrm{Vp}$ and $\mathrm{Vs}$ by Kitsunezaki et al. (1990).

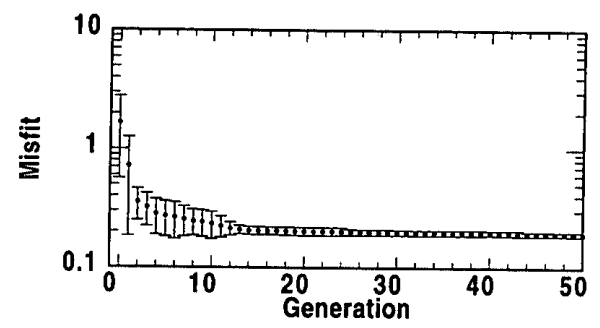

Fig. 14 Plots of misfit values against generation for the inversion of phase velocities in Fig. 13. In the inversion, S-wave velocities and thicknesses for 4 layermodel are parameterized with an introduction of elite selection and dynamic mutation. Results of 10 calculations with different random values are averaged. $\mathrm{km}$ の S 波速度が VSP 探査の結果と異なっている。し かし，それ以外は両者はよく一致している。また，準 ニュートン法による逆解析モデルとは，基盤深さが 2.3 $\mathrm{km}$ となっていることを除けば, 同程度に一致したモデ ルとなっている。準ニュートン法と GAによる逆解析か ら得られた $2 つ の$ 地盤モデルでの基本モードのレイリー 波に対する理論位相速度と観測された位相速度の比較は Fig. 13 に示されている。それぞれの地盤モデルに对する 理論位相速度と観測值の誤差の標準偏差は GA では93 $\mathrm{m} / \mathrm{s}$, 準ニュートン法では $85 \mathrm{~m} / \mathrm{s}$ となる。観測された位相 速度の標準偏差の平均值が $130 \mathrm{~m} / \mathrm{s}$ であることを考慮す れば，2つの地盤モデルによる理論分散曲線はほぼ同程 度に観測值を説明していると考えられる。

このように，非常に良い初期モデルを用いた準ニュー トン法による逆解析と同程度の地盤モデルの推定が GA による逆解析によっても可能であることが確認できた。 GA では特定の初期モデルが必要でなく，位相速度の逆

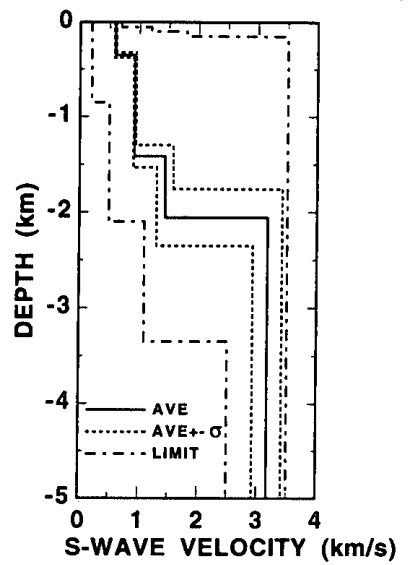

Fig. 15 Results of the GA inversion of phase velocities in Fig. 13. The dotted line indicates structural models inverted from GA inversion of phase velocities in Fig. 13. Results of 10 models from the GA inversions with different random values are averaged. Standard deviation of inverted models is also shown by dotted lines, and search area is indicated by dash-dotted lines.

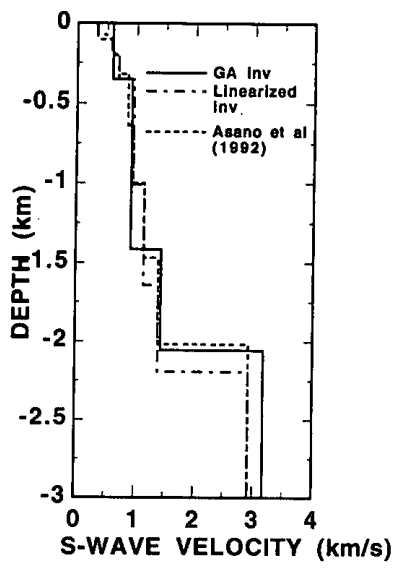

Fig. 16 Comparison of the S-wave velocity model inverted from GA inversion with models from a linearized inversion $^{14)}$ and a VSP exploration at a deep borehole nearby ${ }^{16}$. 
解析において GA は実用性が高いと考えられる。

\section{6、議論とまとめ}

GA に基づいた表面波の位相速度の逆解析方法につい て述べ，数值実験および観測データの逆解析を行い，そ の適用性の検討を行った。

数值実験の結果より, 選択, 交差, 突然変異から成る 単純 GAに, 動的突然変異, エリート選択を加えること によって収束が速くなることがわかった。また, S 波速度 のみを変数としても, $\mathrm{S}$ 波速度と層厚を変数としても，ほ ぼ同様に正解値に収束させることができた。さらに，実 際に微動アレイ観測により得られた位相速度にもこの逆 解析方法を適用し，地震基盤までの S 波速度構造を推定 した。GAによる逆解析結果は既存の深井戸での探査結 果とよく一致しており，妥当な地盤モデルを推定するこ とができた。以上のことから，GA は位相速度の逆解析に おいても大局的な最適モデルの探索に有効であると考之 られる。さらに, GA の特徴として, (1)初期モデルの制約 が少ない, (2)ロバスト性が高い, (3)微分計算が要らない, などの点で, 従来の勾配法にない利点がある。とくに, 地震基盤までの深い堆積層の構造に関しては先駆的な情 報がそしく，適切な初期モデルを必要としないことは微 動アレイ観測による位相速度の逆解析において実用性の 面からも有用である。

GAにはこjした利点がある一方で，従来の勾配法に 比べると欠点もある。例えば，変数のレゾリューション や推定誤差は逆解析結果を評価する上で重要な指標であ るが2)，GAによる逆解析では全く評価できない。した がって，実際には状況に応じて両者を使い分けるべきで あろう。GAによる逆解析で大局的な準最適モデルを探 索し，それを初期モデルとして従来の勾配法などにより 最終的な最適モデルや変数の推定誤差などを求めること ができるであろう。

ここで述べた方法では，選択の基準となる適応度の計 算は勾配法と同じく誤差の 2 乗平均值を使っており，公 配法と同じ誤差曲面での探索を行っている。勾配法に比 べ, GA では適応度の評価はより自由であり, 別の評価関 数や制約条件を使えば, さらに, 探索能力の改善を行う ことが可能性であると思われる。とくに，この研究では 層数を固定しているが，層の分割数の影響や層分割自体 を変数に含めるなどについて今後検討する必要がある。

この研究では, 微動のアレイ観測により得られる位相 速度の逆解析へ GA を適用することを念頭に置いて検 討を行ったが，ここで述べている方法は地震記録から得 られる表面波の群速度の逆解析にも適応度を計算する部 分のみを変更するだけで応用できるものであり，群速度 の逆解析にも GA は有用であると考えられる。

\section{謝辞}

この研究は鹿島小堀研究室鎌形修一氏のアドバイスが
契機となって始められ，多くの議諭をして頂きました。 また，鹿島小堀研究室武村雅之氏，鹿島技術研究所丹羽 正徳氏にも議論して頂きました。また，2名の查読者か らのご意見はこの論文をまとめるに際して参考になりま した。記して感謝いたします。

\section{参考文献}

1）鏡味洋史：微動観湘とその工学的利用, 地学雑誌, Vol. 97 , No. 5, pp.409-422, 1988

2) Horike, M. : Inversion of phase velocity of long-period microtremors to the S-wave-velocity structure down to the basement in urbanized area, J. Phys. Earth, Vol. 33, pp.59-96, 1985.

3) Matsushima T. and H. Okada : Determination of deep geological structures under urban areas using long -period microtremors, Buturi-Tansa, Vol. 43, No. 1, pp. 21-33, 1990

4) Tokimatu, K., K. Shinzawa, and S. Kuwayama: Use of short-period microtremors for Vs profiling, Jour. of Geotechnical Eng., ASCE, Vol.118, No.10, pp.1544 $-1558,1992.10$.

5）例之ば，山中浩明，釜田正毅，武村雅之，高橋克也：関東 平野北西部におけるやや長周期地震動特性, 日本建築学会 大会学術講演梗概集 (北陸), 構造 I, pp.417-418，1992年 8 月

6) Haskell, N.A: The dispersion of surface waves in multilayered media, Bull. Seism. Soc. Am., Vol. 54, pp. 657-679, 1960.

7) Goldberg, D.E. : Genetic algorithms in search, optimization, and machine learning, Addison-Wesley, 1989.

8）小林重信：遺伝的アルゴリズムの現状と課題, 計測と制御, Vol.32，pp.2-9，1993年 1 月

9）西川緯一：遺伝アルゴリズムとその工学的意味, システム/ 制御/情報, Vol. 37, No. 8, pp.445-449，1993年

10）北野宏明編：遺伝的アルゴリズムとその応用，産業図書， 1993

11) Stoffa, P.L. and Sen, M.K. : Nonlinear multipara meter optimization using genetic algorithms: Inversion of plane-wava seismograms, Geophysics, Vol. 56, No.11, pp.1794-1810, 1991.11

12）狐崎長琅，後藤典俊，小林芳正，井川猛，堀家正則，斉藤 徳美，黒田徹，山根一修，奥住去一：地震動予測のために 樑層地盤 $\mathrm{P} \cdot \mathrm{S}$ 波速度の推定，自然災害科学，9-3，pp.1-17, 1990年

13）山村雅幸, 小林重信：遺伝的アルゴリズムによる組合せ最 適化，シミュレーション，第12巻，第 1 号，pp.4-10，1993 年 5 月

14）山中浩明，武村雅之，石田寛，池浦友則，野澤貴，佐々木 透，丹羽正徳：首都圈西部におけるやや長周期微動の観測 と S 波速度構造の推定, 地震 2, 第47卷, pp.163-172, 1994

15）中川徹，小柳義夫：最小二乗法による実験デー夕解析，東 京大小出版会, 1982

16）浅野周三，安井譲，若松邦夫，鈴木宏芳，山水史生，井川 猛：首都圈における地下構造調查 その1東京都府中市に おけるVSP 法探查，日本建築学会大会学術講演梗概集 (北 陸), 構造 I, pp.413-414, 1992年8月

（1994年 6 月10日原稿受理，1994年12月 5 日採用決定） 